\title{
Haemichorea-haemiballism associated with poorly controlled type 2 diabetes mellitus (a video demonstration)
}

\author{
Shun Yamashita, Masaki Tago 두, Shu-ichi Yamashita
}

Department of General Medicine, Saga University Hospital, Saga, Japan

Correspondence to Dr Masaki Tago;

tagomas@cc.saga-u.ac.jp

Accepted 26 March 2021

Check for updates

C) BMJ Publishing Group Limited 2021. No commercial re-use. See rights and permissions. Published by BMJ.

\begin{tabular}{|l|}
\hline To cite: Yamashita S, \\
Tago M, Yamashita S. BMJ \\
Case Rep 2021;14:e242949. \\
doi:10.1136/bcr-2021- \\
242949 \\
\hline
\end{tabular}

\section{DESCRIPTION}

An 84-year-old man with type 2 diabetes mellitus (DM) started to show involuntary movement in his left fingers 2 months prior to examination, which gradually spread to his left shoulder a month later. He had a history of cerebral infarction and right haemiparesis remained. His haemoglobin A1c (HbA1c) had been 7.6\% while taking metformin $1000 \mathrm{mg} /$ day and linagliptin $5 \mathrm{mg} /$ day, which he had decided to discontinue 6 months previously. Because the involuntary movements continued despite the resumption of his oral hypoglycaemic medication, he attended our hospital. He showed haemichorea and haemiballism (HCHB) in his left arm, extending from his left fingers to his shoulder and face (see video 1). His fasting blood glucose was $182 \mathrm{mg} / \mathrm{dL}$ and his HbA1c was 11.7\%. T1-weighted cranial MRI showed a high signal intensity in the right putamen (figure 1A), but fluid-attenuated inversion recovery images and susceptibility-weighted images were normal (figure 1B,C). Therefore, he was diagnosed with diabetic HCHB. Since the voluntary movement persisted despite an appropriate control of blood glucose by linagliptin $5 \mathrm{mg} /$ day and dulaglutide $0.75 \mathrm{mg} /$ week with diet therapy started at the time of his admission to our hospital, we initiated oral administration of haloperidol $0.75 \mathrm{mg} /$ day on the 10th hospital day, subsequently increasing to 1.5 $\mathrm{mg} /$ day on the 17th hospital day. The involuntary movement gradually improved and disappeared on

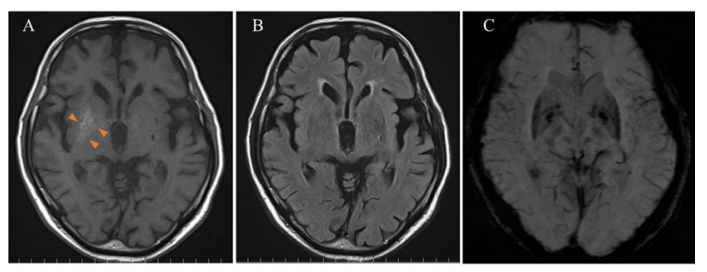

Figure 1 Cranial magnetic resonance images without contrast enhancement at the time of admission. (A) T1weighted image, (B) fluid-attenuated inversion recovery image, (C) susceptibility-weighted image. T1-weighted imaging without contrast enhancement showed high signal intensity in the right putamen (arrowheads), which is compatible with diabetic haemichorea and haemiballism ( $\mathrm{HCHB}$ ). The putamen appeared to be intact on fluid-attenuated inversion recovery imaging and susceptibility-weighted imaging, which implied that cerebral infarction or haemorrhage were much less likely diagnoses.

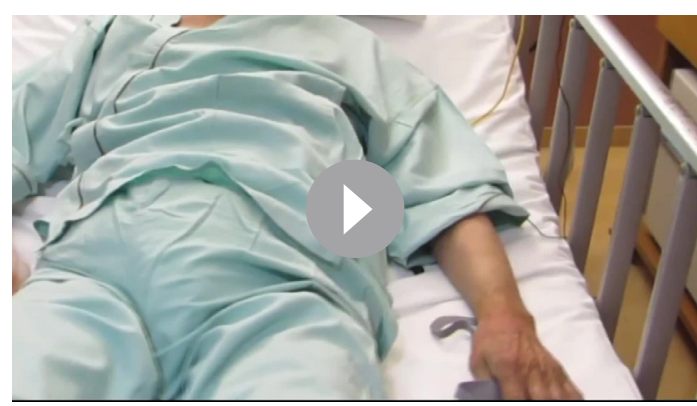

Video 1 Haemichorea-haemiballismus associated with type 2 diabetes mellitus. The video shows jerky, irregular movements that are compatible with chorea and ballism in the patient's left arm, from his fingers to shoulder, including his face, when he is alert and oriented. The involuntary movements did not occur in his sleep.

the 41st hospital day without recurrence even in the absence of haloperidol.

$\mathrm{HCHB}$ is a syndrome that is characterised by unilateral choreic and ballism-like involuntary movements, which can be caused by stroke, DM, autoimmune conditions, infections or drug addiction. ${ }^{12}$ HCHB associated with DM can be a complication of extreme hyperglycaemic due to poor control or a hyperosmolar hyperglycaemic state. ${ }^{1-3}$ When DM is the cause of HCHB, cranial T1-weighted MRI shows high signal intensity on the other side of the basal ganglia, which is diagnostically specific. ${ }^{1-3}$ Importantly, HCHB associated with DM improves slowly with appropriate glycaemic control, ${ }^{1-3}$ sometimes with the help of concomitant use of haloperidol. ${ }^{3}$ Therefore, it is essential to check the state of blood glucose

\section{Learning points}

Haemichorea and haemiballism associated with diabetes mellitus is an unilateral choreic and ballism-like involuntary movements, which is caused by extreme hyperglycaemic due to poor control or a hyperosmolar hyperglycaemic state.

- The finding of high signal intensity on the other side of the basal ganglia on cranial T1-weighted MRI is diagnostically specific.

- Because haemichorea and haemiballism associated with DM improves slowly with appropriate glycaemic control, it is essential to check the state of blood glucose immediately. 
immediately when examining a patient who presents with unilateral choreic or ballism-like involuntary movements.

Acknowledgements We thank Mr. Youjirou Tateishi from Faculty of Medicine, Saga University, Japan for editing our video 1. We thank Mark Cleasby, PhD, from Edanz Group (https://en-author-services.edanz.com/" https://en-author-services. edanz.com/) for editing a draft of this manuscript.

Contributors SY: involved in concept, literature search and drafting of manuscript. MT: involved in concept and literature search. S-IY: involved in concept and revision of manuscript.

Funding The authors have not declared a specific grant for this research from any funding agency in the public, commercial or not-for-profit sectors.

Competing interests None declared.
Patient consent for publication Obtained.

Provenance and peer review Not commissioned; externally peer reviewed.

\section{ORCID iD}

Masaki Tago http://orcid.org/0000-0003-1092-1834

\section{REFERENCES}

1 Ticona J, Zaccone V, Zaman U, et al. Hemichorea-Hemiballismus as an unusual presentation of hyperosmolar hyperglycemic syndrome. Am J Med Case Rep 2020;8:159-61.

2 Bhagwat NM, Joshi AS, Rao G, et al. Uncontrolled hyperglycaemia: a reversible cause of hemichorea-hemiballismus. BMJ Case Rep 2013;2013:bcr2013010229.

3 Jaafar J, Rahman RA, Draman N, et al. Hemiballismus in uncontrolled diabetes mellitus. Korean J Fam Med 2018;39:200-3.

Copyright 2021 BMJ Publishing Group. All rights reserved. For permission to reuse any of this content visit

https://www.bmj.com/company/products-services/rights-and-licensing/permissions/

BMJ Case Report Fellows may re-use this article for personal use and teaching without any further permission.

Become a Fellow of BMJ Case Reports today and you can:

- Submit as many cases as you like

Enjoy fast sympathetic peer review and rapid publication of accepted articles

- Access all the published articles

Re-use any of the published material for personal use and teaching without further permission

Customer Service

If you have any further queries about your subscription, please contact our customer services team on +44 (0) 2071111105 or via email at support@bmj.com.

Visit casereports.bmj.com for more articles like this and to become a Fellow 